\title{
SURVEY AND RESTORATION
}

\author{
Camilla Mileto, Fernando Vegas \\ Universitat Politècnica de València, Camí de Vera S/N, Valencia, Spain - cami2@cpa.upv.es, fvegas@cpa.upv.es
}

Commission VI, WG VI/4

KEY WORDS: Survey, photography, history, restoration, instruments, manual, criteria

\begin{abstract}
:
In addition to the technological evolution over the last two centuries, survey has experienced two main conceptual leaps: the introduction of photography as a tool for an indiscriminate register for reality, and the shift from autographic to allographic survey, phenomena which can generate a distancing effect within the restoration process. Besides, this text presents the relationship between survey in its numerous forms and technologies (manual and semi-manual to more complex ones like scanner-laser) and the restoration of the building, either for establishing a diagnosis, operating or valorizating, illustrating it with examples developed by the authors, as well as the criteria to be applied when documenting a building to be restored, irrespective of the means and technology available in each case.
\end{abstract}

\section{INTRODUCTION}

The fabric of the building is our main source of historical information. A proper documentation of the building fabric is the main basis for a careful restoration project, even if this is not a guaranteed starting point. Detailed knowledge and data of the original materiality of the building open the door to the conservation of imprints and traces of its history, and more indepth knowledge either at present, or with the aid of future technology. The overall simplification of the representation of the building translates into an ignorance which could easily result in unsatisfactory restoration.

Technology linked to documentation has gradually been perfected over time to reach an extremely high level of detail. Traditional manual surveys have gradually been transformed into highly efficient and precise instrumental documentation, especially in the last twenty years. Apart from the absolutely breath-taking technological development of the last 150 years, there have been two main conceptual advances: the introduction of photography as a means of acritical documentation and the shift from autographic to allographic documentation.

\section{PHOTOGRAPHY AND METRIC SURVEY}

The introduction of photography to back up documentary recording of buildings entailed an initial shift from a manualapproached critical survey to an acritical survey, from the visual data selection by humans for representation to the indiscriminate absorption and documentation of reality captured by the lens. This innovation greatly facilitated documentation given its ease and the fact that the task of understanding the building was deferred to the office, even though this deferral entailed a greater risk of misinterpretation due to lack of direct contact.
In fact, shortly after the invention of photography, in 1847 , Viollet le Duc (1814-1879) commissioned some daguerreotypes of Notre Dame Cathedral in Paris as prior documentation and the basis for the metric survey of its restoration project. These daguerreotypes are an extraordinary historical document which also shows the scaffolding that was in place and the restoration tasks that were underway (Zannier, 1991: 34). In parallel, in 1849, John Ruskin (1819-1901) used his newly acquired daguerreotype camera to document the buildings of Venice (Costantini \& Zannier, 1986). These daguerreotypes did not replace the plans and watercolours he took of the city, but complemented them. All this documentation is now being used to compare the current condition of these buildings with that of over 150 years ago (Quill 2003).

Two years later - in 1851 - the inspector of historic monuments Prosper Mérimée (1803-1870) of the French Commission for Historical Monuments, hired Auguste Mestral (1812-1884) and Gustave Le Gray (1820-1884) to execute the Mission Héliographique, documenting the city of Carcasonne photographically as part of the project for the restoration of its fortifications, entrusted to architect Viollet le Duc (1814-1879) (Frizot, 1994: 66). Viollet used the photographs of the mission to produce his before and after watercolours of the intervention. Today, these are irreplaceable documentation of the conditions of the fortified city prior to the famous intervention. The same is true of the photographs by Charles Marville, requested by Baron Eugène Haussmann to document the appearance of the city before the major urban changes that took place during his major reform of Paris (1853-1870) (Zannier, 1991: 30). Unlike the previous ones, these photographs are merely documentary and are of no metric value.

Technological evolution in the sphere of the survey of historic buildings was off to a frenetic start as in 1851, when a French officer called Aimé Laussedat (1819-1907) developed the first photogrammetric devices and methods (Laussedat, 1993: 99- 
100). In 1858 German architect Albrecht Meydenbauer (18341921), a pioneering visionary of the preservation of built cultural heritage, independently developed photogrammetric techniques for the documentation of buildings. In 1885 the ruins of Persepolis became the first archaeological site to be recorded using photogrammetry (Zannier, 1991: 31-35; Albertz, 2001: 19-25). Neither Ruskin's daguerreotypes nor Viollet le Duc's Heliographic plates registered measurements. Photogrammetry, a 3D measuring technique that uses photographs for measurement, had the great advantage of measuring architectural objects without needing to be in contact with them.

The aerial documentation of buildings, cities and archaeological sites also appeared at the same time thanks to French architect, engraver, and lithographer Alfred Guesdon (1808-1876). Guesdon was a draftsman specialized in the documentation of monuments and archaeological sites (Baydal 2016) who became famous circa 1850 for producing over 100 aerial lithographs of European cities. For a long time it was thought that these lithographs had been executed in a hot air balloon (Gámiz, 1999: 174-175) or based on photographs taken from one. There are two reasons why this seems impossible. Firstly, there is no record of Guesdon having been on a hot air balloon over any of the cities he drew, and secondly and most importantly, it was technically impossible to take photographs from balloons in 1850, given the long exposure times required. Paradoxically, this lithographer had an extraordinary capacity to produce highly detailed aerial perspectives based on the plans of cities and data fields with geometric triangulation meshes (Stroffolino 2012).

As for aerial documentation, it was Gaspard-Félix Tournachon (1820-1910), better-known as Nadar, who took the first aerial photograph from a tethered balloon in 1858. This photograph no longer exists (Zannier, 1991: 30-31; Frizot, 1994: 391). The first surviving aerial photograph was taken in Boston in 1860 by James Wallace Black (1825-1896), who titled it: "Boston, as the Eagle and the Wild Goose see it" (Encyclopaedia, 2008: 164). Aerial photogrammetry was developing in parallel to these early aerial photographs. Frenchman Laussedat had first tried aerial photogrammetry using kites, and shortly after using tethered balloons with little success. The first more or less successful aerial photograph was taken from a kite in 1888 by Arthur Batut (1846-1918) (Zannier, 1993: 88). From analogical photography to digital photography, and from photographs from kites to the modern technology of drones used for photogrammetry or UAVs (Unmanned Aerial Vehicles) the technological evolution has been boosted primarily by military demands. In fact, as in so many other things, this is proof of another sad reality: advances in technology for documenting buildings often stem from military technology, or originate from prior use in armed conflicts.

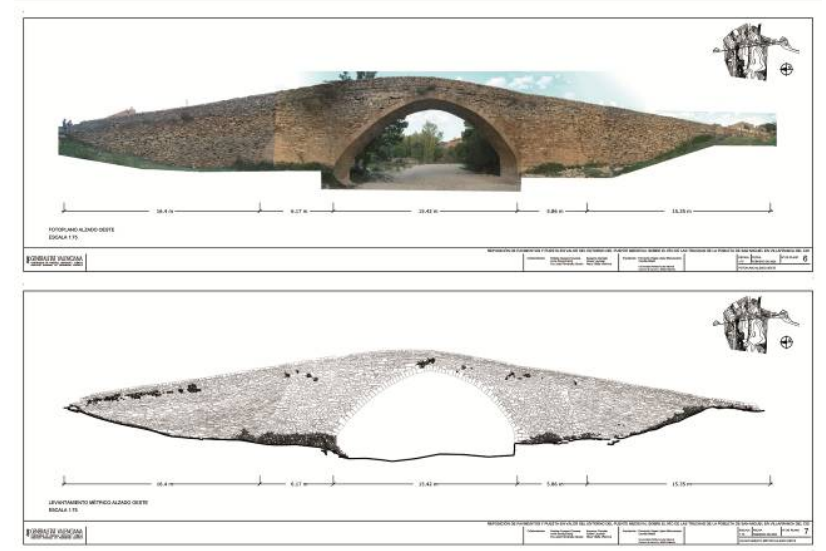

Fig. 1. Manual survey + photography: Elevation of the bridge at Villafranca del Cid (Castellón, Spain)

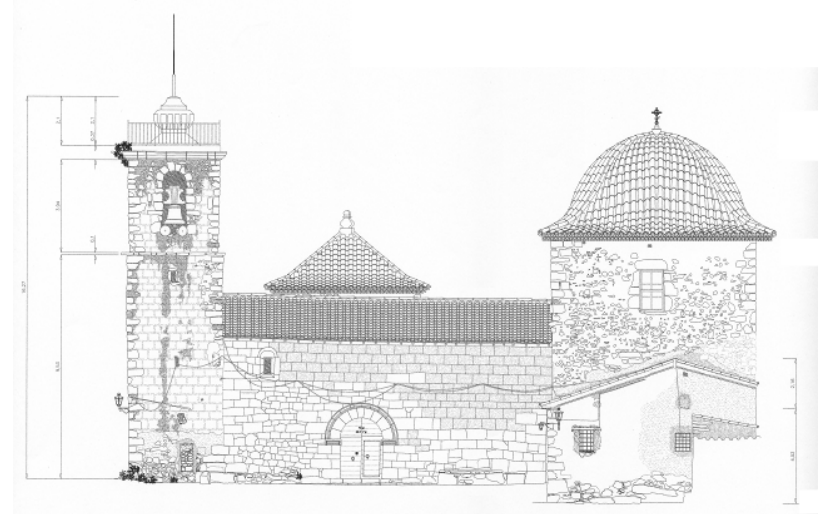

Fig. 2. Semi-manual survey: Elevation of the Church in La Pobla de la Benifassà (Castellón, Spain)
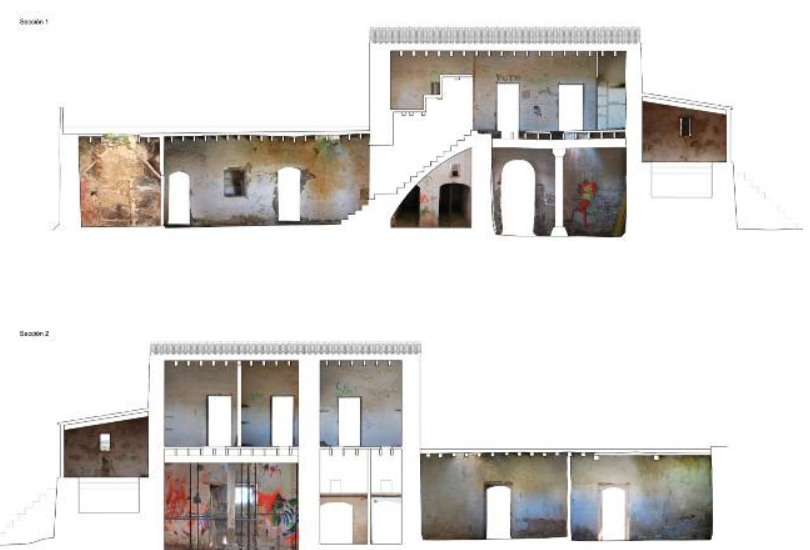

Fig. 3. Semi-manual survey. Sections of Can Ramón (Formentera, Spain) 


\section{FROM AUTOGRAPHIC TO ALLOGRAPHIC DOCUMENTATION}

While the introduction of photography already led to a phenomenon of alienation of survey replacing the human eye and pencil drawing with a machine which captured reality without discriminating, going from autographic to allographic surveys has led to a further stage of alienation in the world of metric documentation.

In fact, autographic survey, that is to say the documentation made by the architect in charge of the project to be completed, encourages the co-existence of architect and building, resulting in intimate knowledge regardless of the geometrical precision involved in the task. Without a doubt, this co-existence is even greater if the graphic survey, or at least the initial approach to the building, is carried out manually using diagrams, sketches, etc. However, this is not always possible. Especially in recent years the degree of specialization required for the documentation of buildings using new technological tools has been such that it is difficult to propose any option that is not an allographic survey carried out by someone other than the architect in charge of the project. Allographic surveys prompt a certain distancing between the architect and building to be restored, especially if the documenting and diagnosis are also carried out by a third person. This distance can be avoided in part or in full if enough time is spent trying to understand the building as a whole

In any case, the greater or lesser extent to which allographic surveys affect the restoration process depends on how a restoration process is understood. If the documentation and diagnosis of the building are understood as a process mainly independent and separate from the project, it seems unlikely that it will have a major impact on it. However, if the process for documenting the building prior to restoration is seen as an emotional one, linked to its atmosphere, ambiance and personal research for its conservation and use in the future, then it would be advisable for the architect in charge of the restoration to compile information through allographic documentation to achieve this.

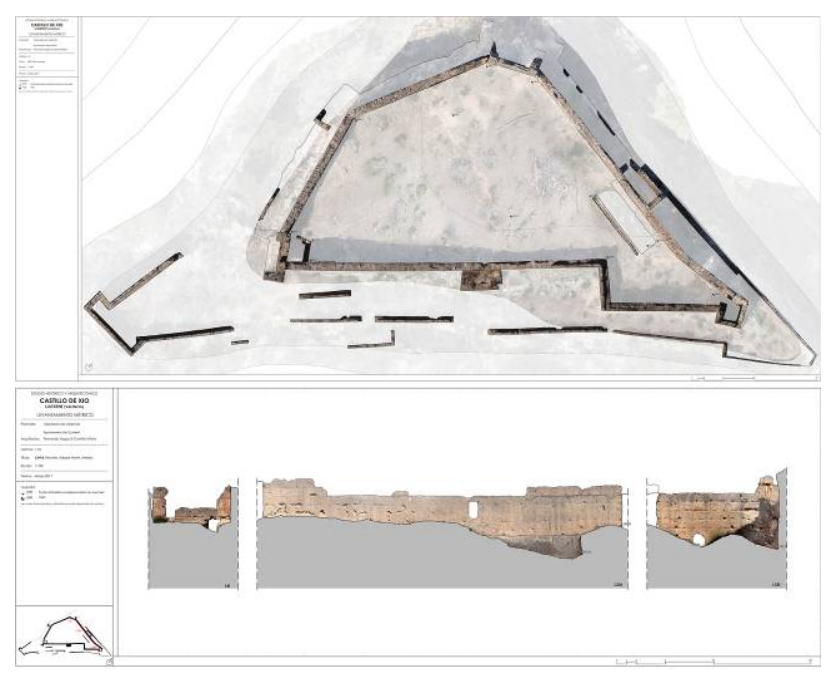

Fig. 4. Drone survey: Castle of Xió, Llutxent (Valencia, Spain)

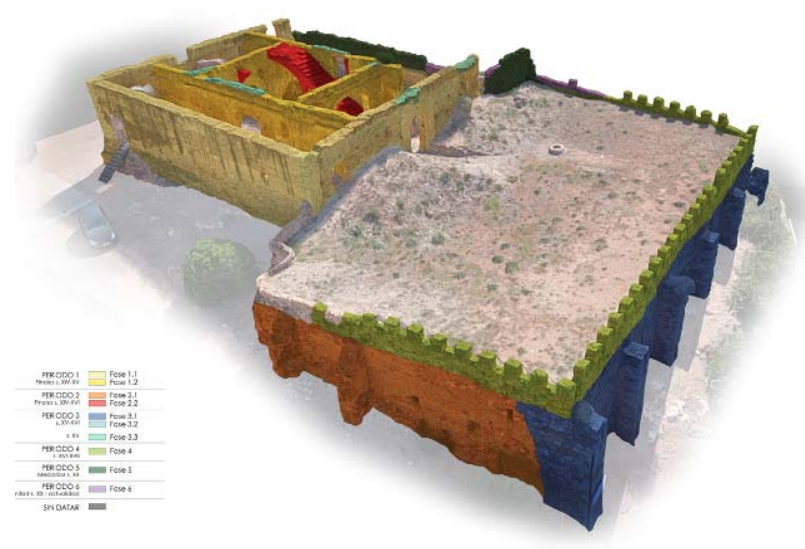

Fig. 5. Drone + scanner-lasser: 3D hypothesis of the relative chronology at Castle of Petrés (Valencia, Spain)

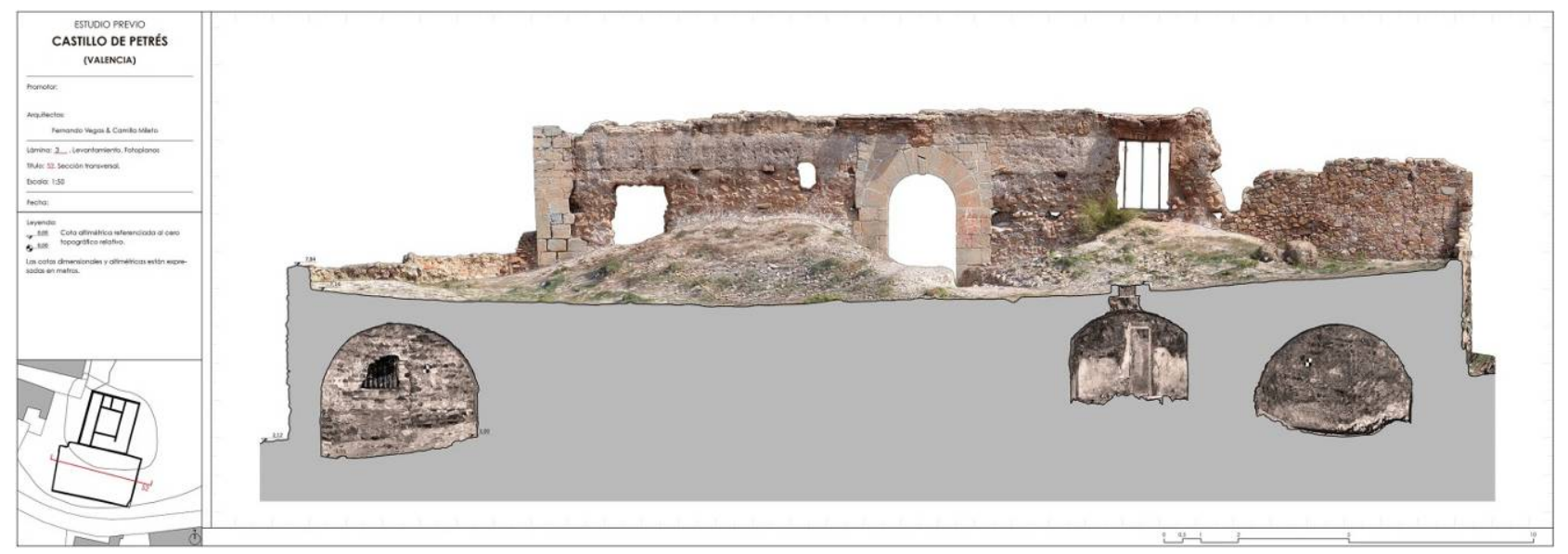

Fig. 6. Drone + scanner-lasser: Section of the Castle of Petrés (Valencia, Spain) 


\section{DOCUMENTATION AND RESTORATION}

It could be stated that there is a correlation between the type of use of tools for documentation and the interpretation of restoration made by the architect in charge of the project. For instance, a detailed survey could be carried out on a cornice with the predetermined aim of reproducing it or simply to find out more about it. But, in general, it can be stated that documentation is linked to the production of a diagnosis for the building, to operational use, or to valorizing the building.

\subsection{Diagnosis}

Establishing a diagnosis to serve as a basis for understanding of the situation has two main aims: prevention or later restoration. On the one hand, setting up a diagnosis for preventive actions can translate into documents such as catalogues, geographical and/or geological location in the territory, risk charters, databases, etc. On the other, diagnosis is of genuine use as a basis for the future restoration project. Precise surveys, no matter whether manual or technological, make it possible to interpret the occasional damage, deformations and structural lesions of the building and the mapping of the façades, crosssections and floor plans of the materials, degradation, stratigraphy, etc. The establishment of a diagnosis is an action which ought to be common to all restoration actions, irrespective of the chief architect's concept or criteria of restoration.

\subsection{Operational use}

This use is closely linked to the view of restoration held by the architect in charge, and from the outset the aim of the survey can be considered to be documentation for research on the building, mostly for conservation purposes, collecting data for the partial or full reproduction of elements that are missing or deteriorating for some reason, for producing a copy, etc. At this point it is important to note the importance of simulation, which has been greatly facilitated by the advances in documentation technology, as a design tool.

Technology and precision in metric documentation have been perfected to such a point that possibilities are opening up to the reproduction of elements of a building or buildings in every aspect in cases where these have been destroyed. A great number of immediate and deferred reconstructions of churches (Frauenkirche in Dresden, etc.), bridges (Ponte Pietra and Ponte di Castelvecchio in Verona, Ponte della Trinità in Firenze, Mostar bridge, etc.), monuments (Royal Castle of Warsaw, Royal Palace of Berlin, etc.) or the entire fabric of historic centres (Warsaw, Hildesheim, etc.), following their destruction by wars and earthquakes, have experienced many difficulties. In most cases, these reconstructions did not rely on detailed manual documentation such as the survey made of Warsaw during the 1930s (Salas Ballestín, 2008), a chilling premonition of what would happen in later years. However, despite its repeated use throughout history (Nerdinger, 2010) and although tools exist for a detailed documentation process, complete reconstruction is an exceptional action to be avoided by tackling the source of the problem, that is, by preventing destruction as far as possible.

\subsection{Valorization}

Valorization is the interpretation of the data for dissemination among the general or specialist public which new documentation technologies have boosted or taken to unimaginable lengths. Whether these buildings are partially or fully in ruins or existing, there is the possibility of 3D reconstruction of a former state, through the creation of augmented reality experiences, 3D printing, research, study, experimentation, etc.

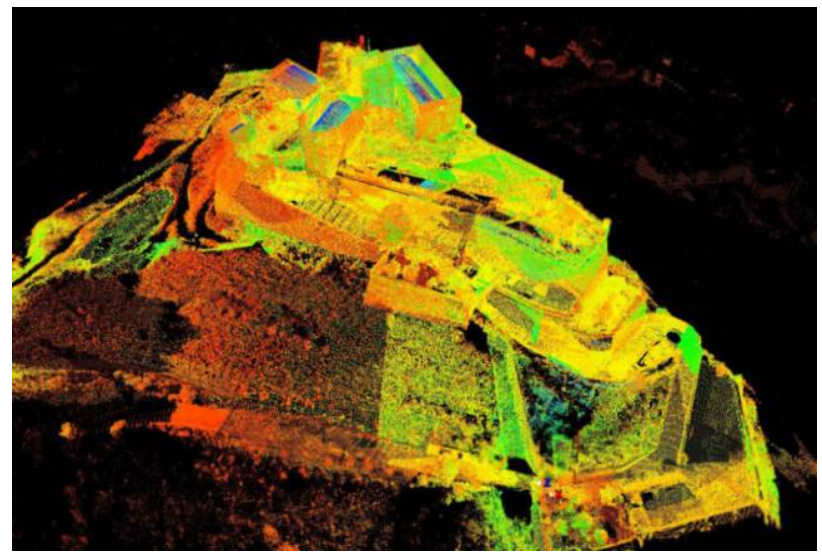

Fig. 7. Scanner-laser survey: Point cloud of the Castle of Monzón (Huesca, Spain)

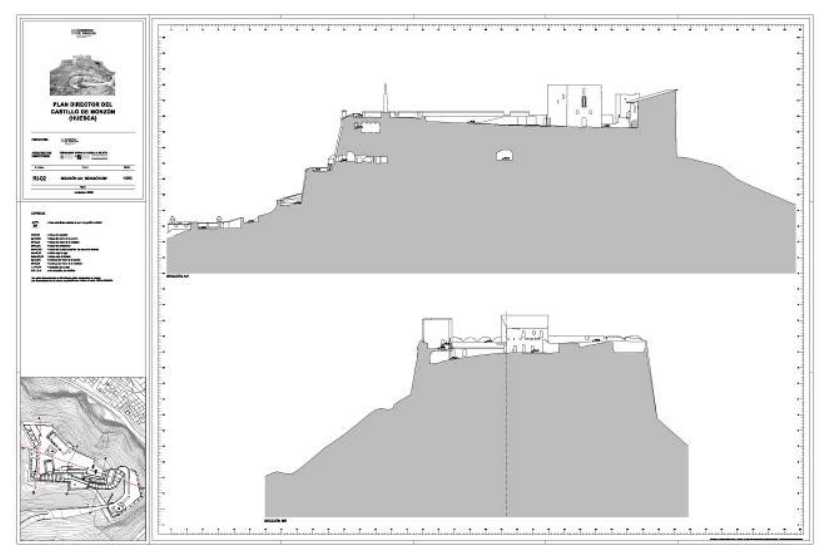

Fig. 8. Scanner-laser survey: Sections of the Castle of Monzón (Huesca, Spain)

\section{CONCLUSIONS}

The proposed documentation to be carried out must always be based on the objetives pursued and means available. A lack of technological means does not necessarily hinder the execution of precise documentation. Attention paid in documentation tasks is not directly proportional to the technology deployed. Rudimentary manual or semimanual autographic surveys offer the advantage of direct contact with the building, compared with the distance generated by allographic instrumental surveys which compile extensive data without discrimination. In any case, despite the potential alienation caused by the acritical nature of instrumental recording and the allographic or delegated execution of a survey, the documentation of a building can and must make use of available technological media when necessary, providing that the architect in charge of the restoration spends enough time assimilating and critically analysing the information collected. The efficient survey and documentation of a historic building can never fully guarantee a suitable restoration, but they are the appropriate means to provide extensive in-depth information on the building, creating a solid base for all diagnoses, operations or valorizations. 


\section{ACKNOWLEDGEMENTS}

We want to thank Sat Survey SL for the collaboration in the survey of the Castle of Monzon (Huesca, Spain) and Pablo Rodríguez Navarro \& Teresa Gil Piqueras for the survey of the Castle of Xió in Llutxent (Valencia, Spain) and Petrés (Valencia, Spain), excellent professionals who were responsible for the allographic surveys that partially appear in the figures of this paper.

\section{REFERENCES}

Albertz, J., 2001. Albrecht Meydenbauer - Pioneer of photogrammetric documentation of the cultural heritage. Proceedings of the XVIII International Symposium of CIPA, ICOMOS / UNESCO / ISPRS, Postdam.

Baydal, V., 2016. Gueston, el mite de Dèdal en la València de 1853. Històries de València, CulturPlaza.

Colonel L., 1891. Notice sur l'histoire des applications de la perspective à la Topographie et à la Cartographie, Extrait de Paris-Photographe, p. 4, quoted by Zannier, I. 1993. Storia e técnica della fotografía. Editori Laterza, Roma.

Costantini, P. \& Zannier, I. (eds.), 1986. I dagherrotipi della collezione Ruskin, Arsenale Editrice, Venezia.

Hannavy J. (ed), 2008. Encyclopedia of nineteenth-century photography, Volume 1. CRC Press, London.

Frizot, M. (ed). 1994. A new history of fotography, Könemann, Köln.

Gámiz Gordo, A., 1999. Ciudades dibujadas a vista de pájaro o retratadas desde globo: Guesdon y Clifford hacia 1853. Revista de Historia y Teoría de la Arquitectura n. 1, Universidad de Sevilla, España.

Nerdinger, W. (ed). 2010. Geschichte der Rekonstruction, Konstruction der Geschichte, Prestel Verlag, München.

Quill, S., 2003. Ruskin's Venice. The stones revisited, Lund Humphries, Burlington.

Salas Ballestín, J. C., 2008. The reconstruction of Warsaw after the Second World War. Loggia, Arquitectura \& Restauración n. 21, pp. 64-75.

Stroffolino, D., 2012. L'Europa a volo d'uccello. Dal Cinquecento ad Alfred Guesdon, Edizione Scientifiche Italiane.

Zannier, I., 1991. Architettura e fotografía, Editori Laterza, Roma.

Zannier, I., 1993. Storia e técnica della fotografía. Editori Laterza, Roma. 